\title{
Enhancement of stability of a lipase by subjecting to three phase partitioning (TPP): structures of native and TPP-treated lipase from Thermomyces lanuginosa
}

\author{
Mukesh Kumar ${ }^{1}$, Joyeeta Mukherjee ${ }^{2}$, Mau Sinha' ${ }^{1}$ Punit Kaur', Sujata Sharma' ${ }^{1}$ Munishwar Nath Gupta ${ }^{3^{*}}$ \\ and Tej Pal Singh ${ }^{1}$
}

\begin{abstract}
Background: The lipase enzyme converts long chain acyltriglycerides into di- and monoglycerides, glycerol and fatty acids. The catalytic site in lipase is situated deep inside the molecule. It is connected through a tunnel to the surface of the molecule. In the unbound state under aqueous conditions, the tunnel remains closed. The tunnel can be opened when the enzyme is exposed to a lipid bilayer or a detergent or many hydrophobic/hydrophilic surfaces.

Results: In the present study, the lipase was subjected to three-phase partitioning (TPP) which consisted of mixing in tert-butanol and ammonium sulphate to the solution of lipase in the aqueous buffer. The enzyme formed an interfacial precipitate between the tert-butanol rich and water rich phases. The stability of the enzyme subjected to TPP was found to be higher $\left(T_{m}\right.$ of $\left.80^{\circ} \mathrm{C}\right)$ than the untreated enzyme $\left(T_{m}\right.$ of $\left.77^{\circ} \mathrm{C}\right)$. The activity of the enzyme subjected to TPP $(3.3 \mathrm{U} / \mathrm{mg})$ was nearly half of that of the untreated one $(5.8 \mathrm{U} / \mathrm{mg})$. However, the activity of the treated enzyme was higher $(17.8 \mathrm{U} / \mathrm{mg})$ than the untreated one $(8.6 \mathrm{U} / \mathrm{mg})$ when a detergent was incorporated in the assay buffer.
\end{abstract}

Conclusions: The structure determination showed that the substrate binding site in the treated enzyme was more tightly closed than that of the untreated protein.

Keywords: Lipase, Complexes, Crystal structures, Three-phase partitioning, Stability, Activity, New binding site

\section{Background}

Enzymes offer a more sustainable option for catalyzing chemical processes [1]. Hence, enhancing their stability and activity is a worthwhile goal. The present work describes efforts to understand how a simple process called three phase partitioning (TPP) resulted in altering both stability and activity of a lipase from Thermomyces lanuginosus (TLL). Lipases (triacylglycerol hydrolases; EC 3.1.1.3) have been extensively used in both aqueous media as well as non aqueous media [1-8]. One of the main reasons of their large-scale usage has been their

\footnotetext{
*Correspondence: munishwar48@yahoo.co.uk

${ }^{3}$ Department of Biochemical Engineering and Biotechnology, Indian

Institute of Technology Delhi, New Delhi, India

Full list of author information is available at the end of the article
}

broad specificity $[8,9]$. Lately, this range has been further enlarged by the reports on the lipase catalysed promiscuous reactions [10-13]. The catalytic promiscuity refers to enzymes belonging to a particular class in the enzyme classification (EC) system catalyzing reactions of the type which are generally catalyzed by another class of enzymes. Lipases, classified as hydrolases, have been shown to catalyze many $\mathrm{C}-\mathrm{C}$ bond formation reactions $[10,11,14,15]$. It is believed that in such cases, substrates interact with the active site in a manner different from that observed by natural substrates [10].

The lipase from Thermomyces lanuginosus (TLL) is a glycosylated hydrolase which consists of 269 amino acid residues with a molecular weight of about $29 \mathrm{kDa}$. It has an optimum $\mathrm{pH}$ of 11-12 [16]. The structure of TLL was reported earlier in the native state which showed that
Chemistry Central

(c) 2015 Kumar et al. This article is distributed under the terms of the Creative Commons Attribution 4.0 International License (http://creativecommons.org/licenses/by/4.0/), which permits unrestricted use, distribution, and reproduction in any medium, provided you give appropriate credit to the original author(s) and the source, provide a link to the Creative Commons license, and indicate if changes were made. The Creative Commons Public Domain Dedication waiver (http://creativecommons.org/ publicdomain/zero/1.0/) applies to the data made available in this article, unless otherwise stated. 
the substrate binding cleft was in the closed form [17]. The structure determined in the presence of a detergent showed open conformation [18]. TLL is among the most frequently used lipases in biotechnology [19] and its applications include its use in catalysing $\mathrm{C}-\mathrm{C}$ bond formation because of its promiscuous activity [20].

It was recently observed that TLL subjected to three phase partitioning under optimized conditions showed about 2-fold increase in the rates of hydrolytic activity of the lipase. It was also observed that the same lipase preparation showed 5-fold increase in the initial rates of a promiscuous reaction; the aldol reaction between 4-nitrobenzaldehyde and acetone carried out with $60 \%$ acetone as the reaction medium (Scheme 1) [M. N. Gupta, unpublished results].

TPP consists of precipitating a protein at the interface of two layers formed by the addition of tert-butanol and ammonium sulphate to a protein solution [21-26] (Fig. 1). It is essentially the precipitation of the protein by simultaneous addition of ammonium sulphate and tert-butanol at appropriate concentrations. However, unlike ammonium sulphate precipitation, this TPP often (though not always) results in subtle structural changes. This makes TPP valuable for wide range of applications such as protein purification, protein refolding and improving the catalytic efficiencies of the enzymes in both aqueous and non aqueous media [21-31]. The technique was introduced by Lovrein's group [21] who emphasized its importance in protein isolation and concentration [22]. The complexity of the mechanism by which it works was discussed adequately by Lovrein et al. [27], and more recently in the context of protein refolding [26]. There have been quite a few reports on the effect of TPP treatment on the structure and function of many enzymes and proteins [21-31]. In few cases, it has been clearly shown that the specific activity of the pure enzyme increased after being subjected to TPP $[24,25,29]$. Many years back, we had reported an X-ray crystallographic study comparing the structure of the untreated and TPP treated proteinase K [28]. The structural work indicated that the higher activity of Proteinase $\mathrm{K}$, in both aqueous buffers and low water media primarily arose from greater accessibility of the substrate to the active site and overall higher molecular flexibility of Proteinase $\mathrm{K}$ as a result of the treatment. The effect of TPP treatment on alpha chymotrypsin was even more dramatic. The enzyme subjected to TPP showed significantly high activity in both aqueous and non-aqueous media [23]. When attempts were made to crystallize the alpha chymotrypsin subjected to TPP, selective autolysis generated a 14 amino acid peptide which was found to bind to the active site of the enzyme [32]. The enhanced protein flexibility has also been identified as one of the

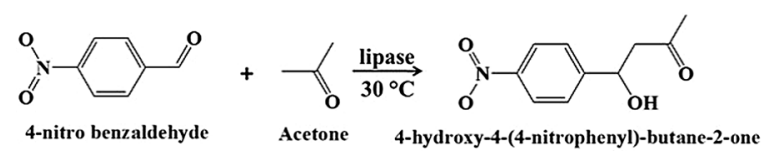

Scheme 1 Aldol condensation reaction catalyzed by Thermomyces lanuginosus lipase

important causes of catalytic promiscuity [10]. One of our groups have recently reported that lyophilized preparation of subtilisin treated with $6 \mathrm{M}$ urea (a highly flexible structure) showed quite high catalytic promiscuity with respect to the aldol condensation (Scheme 1) [33]. Hence, it was naturally of interest to investigate whether in the case of TLL subjected to TPP as well, the high initial rates of catalytic promiscuity arose from similar causes, that is, enhanced flexibility of the protein molecule especially around the active site.

In the present work, we report the protein structures based upon X-ray crystallographic studies of TLL including (1) native untreated form (TLL), (2) TLL after being subjected to three-phase partitioning (TPP-TLL). These structures are discussed alongwith the results from the biochemical studies. It was found that TPP of TLL, contrary to what was expected, resulted in the introduction of rigidity around the active site.

\section{Results and discussion}

\section{Activity of TLL and TPP-TLL}

TPP treatment has, in many cases, resulted in improvement of the catalytic rates of the various enzymes by the marginal to moderate degrees [23, 24, 28-31]. As indicated in the introduction, TLL subjected to TPP under optimized conditions showed an increase in the initial rates of hydrolytic activity from 8.6 to $17.8 \mathrm{U} / \mathrm{mg}$ protein (Table 1). The assay for measuring this activity is carried out in the presence of detergents [34]. Like many lipases the substrate binding site in the native TLL is shown to have a closed conformation such that the active site residues of the enzyme are inaccessible for the interaction with substrates [18]. The detergents are reported to cause an opening of the substrate binding site thereby rendering the active site accessible to the substrates [35]. In the present work both native TLL and TLL subjected to TPP were tested for enzymatic activity in the absence of detergents as well. The TPP-TLL showed that the specific activity of lipase decreased from $5.8 \mathrm{U} / \mathrm{mg}$ protein to $3.3 \mathrm{U} / \mathrm{mg}$ protein when the activities were measured in the absence of detergents (Table 2). This is an unusual result as all the consequences of TPP treatment of enzymes reported so far in the literature either show no change or an increase in biocatalytic activity [28-31,36]. Measurements of melting temperature $\left(\mathrm{T}_{\mathrm{m}}\right)$ by recording 


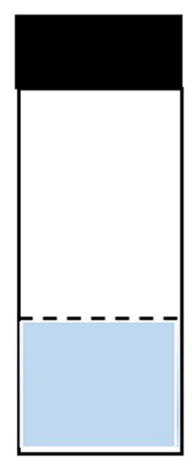

Aqueous ammonium sulphate and enzyme solution

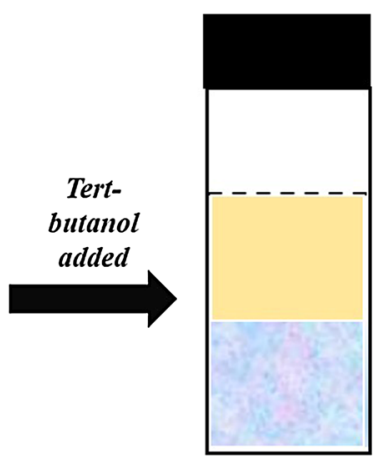

Enzyme precipitate begins to form

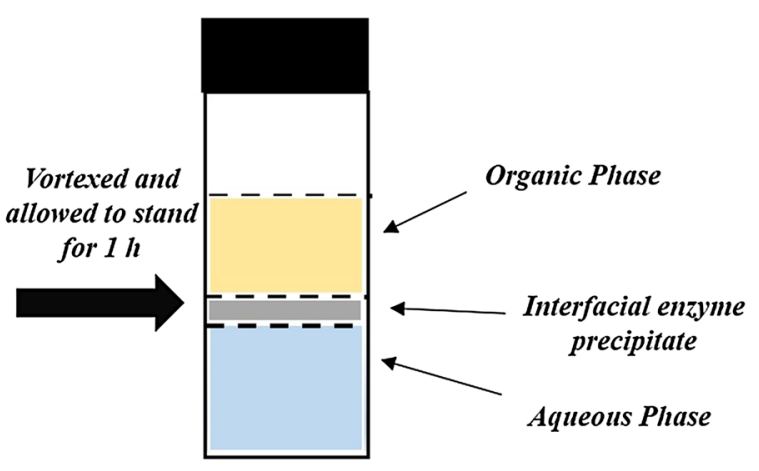

Three phases are formed

The enzyme forms a separate phase as the interfacial precipitate

Fig. 1 Schematic diagram of the three phase partitioning of TLL

Table 1 Three phase partitioning of Thermomyces lanuginosus lipase (TLL) at $25^{\circ} \mathrm{C}$

\begin{tabular}{|c|c|c|c|c|}
\hline & Protein $(\mathrm{mg} / \mathrm{mL})$ & Activity $(\mathrm{U} / \mathrm{mL})$ & Specific activity (U/mg protein) & Fold Increase \\
\hline \multicolumn{5}{|c|}{ Assay in the absence of Triton X-100 } \\
\hline TLL & 17.5 & 102 & 5.8 & - \\
\hline TPP-TLL & 0.22 & 0.72 & 3.3 & 0.57 \\
\hline \multicolumn{5}{|c|}{ Assay in the presence of Triton X-100 } \\
\hline TLL & 17.5 & 151 & 8.6 & - \\
\hline TPP-TLL & 0.22 & 3.91 & 17.8 & 2.1 \\
\hline
\end{tabular}

The Thermomyces lanuginosus lipase was subjected to three phase partitioning as described in the materials and methods section. Experiments were carried out in triplicate and percentage error in each reading in a set was within $3 \%$. The activity was determined using pNPP assay and protein using bradford method

the CD spectra of both untreated TLL and TLL subjected to TPP over a range of temperatures (Fig. 2) showed that the TPP-TLL had a $\mathrm{T}_{\mathrm{m}}$ of $80{ }^{\circ} \mathrm{C}$ whereas the untreated enzyme had a $T_{m}$ of $77^{\circ} \mathrm{C}$. The $T_{m}$ values reflect how easy or difficult it is for a protein to unfold. The increase in the value of $\mathrm{T}_{\mathrm{m}}$ indicated that the enzyme has become more rigid after the TPP-treatment.

However, when assayed in the presence of detergent triton $\mathrm{X}-100$, the TPP-TLL showed an increase in the specific activity from $3.3 \mathrm{U} / \mathrm{mg}$ protein to $17.8 \mathrm{U} / \mathrm{mg}$ protein (Table 1). On the other hand, the native TLL showed an increase in the specific activity from $5.8 \mathrm{U} / \mathrm{mg}$ proteins to $8.6 \mathrm{U} / \mathrm{mg}$ proteins. This shows that the presence of detergent has a more marked effect on the specific activity of the TPP-TLL. In this case, the opening of the lid not only resulted in the more active "open" conformation (which is a well known phenomenon) but also presumably reversed the introduction of more rigidity in the active site by TPP treatment.

The lipase-detergent interactions have been exploited in multiple ways [8]. The most well known among these is via "interfacial activation". This leads to the movement of the molecular lid (present in several lipases including TLL) away from the active site access and makes the active site more accessible. This "lid opening" has also been achieved by immobilization [37, 38] and bioimprinting $[39,40]$.

\section{Structure of the untreated native lipase}

The structure of the native TLL determined at 2.30 $\AA$ showed that protein chain adopted an $\alpha / \beta$ fold (Fig. 3). It consisted of $10 \alpha$-helices, $\alpha 1$ (residues, Ser3-Ala20), $\alpha 2$ (residues, Cys41-Lys46), $\alpha 3$ (residues, Ile86-Gly91), $\alpha 4$ (residues, Asp111-His135), $\alpha 5$ (residues, Ser146-Arg160), $\alpha 6$ (residues, GLy178Gln188), $\alpha 7$ (residues, Ile202-Leu206), $\alpha 8$ (residues, Pro208-Gly212), $\alpha 9$ (residues, Thr231-Asp234) and $\alpha 10$ (Ile255-Leu259), and $10 \beta$-strands, $\beta 1$ (residues, Asp48-Ser58), $\beta 2$ (residues, Val63-Asn71), $\beta 3$ (residues, Lys74-Arg81), $\beta 4$ (Asp96-Ile100), $\beta 5$ (Cys107His110), $\beta 6$ (residues, Arg139-His145), $\beta 7$ (residues, Asp165-Gly172), $\beta 8$ (residues, Gly192-Thr199), $\beta 9$ 
Table 2 The distances $(\AA)$ between atoms of residues from opposite sides of the substrate binding cleft indicating the very closed, closed and open states of substrate binding channel

\begin{tabular}{llllr}
\hline Side 1 & Side 2 & $\begin{array}{l}\text { TPP-TLL } \\
\text { (PDB id: 4FLF) }\end{array}$ & $\begin{array}{l}\text { TLL } \\
\text { (PDB id:4ZGB) }\end{array}$ & $\begin{array}{c}\text { Detergent-treated } \\
\text { (PDB id: 1GT6) }\end{array}$ \\
\hline 86 ILE CD1 & ILE259 CD2 & 3.99 & 5.48 & 19.35 \\
87 GLU CG & LEU255 CD1 & 4.39 & 5.99 & 20.17 \\
89TRP CZ3 & VAL203 CG2 & 4.12 & 4.62 & 7.78 \\
90ILECD1 & VAL203 CG2 & 4.14 & 4.47 & 18.12 \\
93LEUCD2 & PRO207CG & 4.21 & 5.12 & 9.03 \\
95 PHE O & TYR213-OH & 3.20 & 3.40 & 2.57 \\
95 PHECZ & PRO208CD & 3.81 & 5.34 & 8.21 \\
95 PHECE2 & PHE211CE1 & 4.33 & 5.11 & 6.90 \\
95PHE CD2 & PHE211CZ & 3.86 & 4.20 & 6.18 \\
95PHE CG & PHE211CG & 4.37 & 4.65 & 6.07 \\
95PHE CD2 & PHE211CD2 & 4.43 & 5.32 \\
95PHE CD2 & PHE211CD1 & 3.67 & 5.15 & 7.60 \\
95PHE CD2 & PHE211CE1 & 4.06 & 4.87 & 7.39 \\
95PHE CD2 & PRO208CD & 4.06 & 5.56 & 7.35 \\
95PHE CZ & PRO208CD & 4.04 & 5.34 & 5.84 \\
95PHE CD1 & PRO207CG & 3.81 & 3.74 & 8.39 \\
95PHE CE2 & PRO208CG & 3.69 & 6.30 & 9.23 \\
97 LEUCG & TYR213 CZ & 4.70 & 4.22 & \\
\hline
\end{tabular}

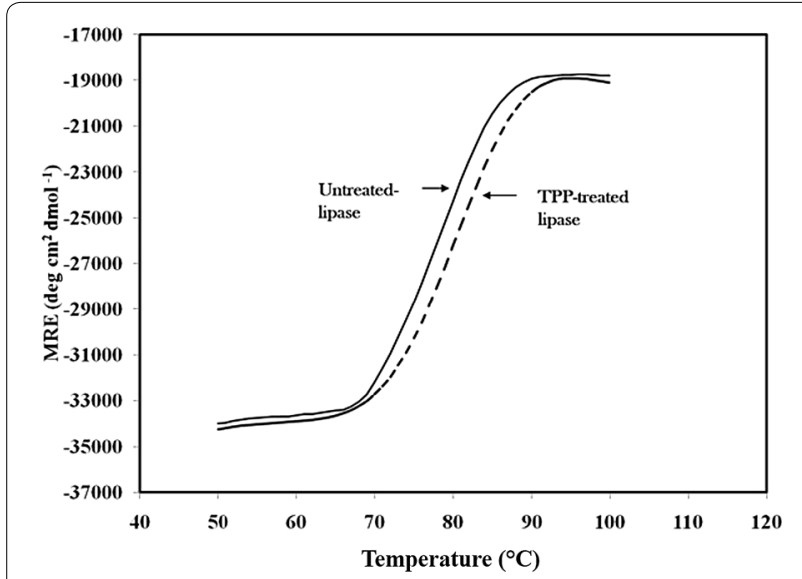

Fig. 2 Determination of the melting temperature of TPP-TLL using circular dichroism. Thermal denaturation curves were determined directly by monitoring the ellipticity changes at $222 \mathrm{~nm}$. The samples with a concentration of $0.2 \mathrm{mg} \mathrm{mL}^{-1}$ were used. The temperature of sample solution was raised linearly by $1{ }^{\circ} \mathrm{C} \mathrm{min}-1$ from 50 to $100^{\circ} \mathrm{C}$. The heating curves were corrected for an instrumental baseline obtained by heating the buffer (10 mM sodium phosphate, $\mathrm{pH} 7.0$ ) alone. The untreated lipase is shown with solid line and the TLL subjected to TPP is shown with dashed line

(residues, Glu219-Lys223) and $\beta 10$ (residues, Asp234Ile238). The active site residues in this lipase are Ser146, His258 and Asp201 and catalytic mechanism works in a manner similar to that of serine proteases [28]. The catalytic triad is located inside a deep cleft which is formed with the help of two segments, consisting of $\alpha$-helix, $\alpha 4$ and $\beta$-strands, $\beta 4$ and $\beta 5$ (Wall-1) and $\alpha$-helices $\alpha 6, \alpha 7$ and $\alpha 8$ (Wall-2). Several van der Waals interactions are observed between the two residues of two walls (Table 2). This represents the closed state of lipase whereby the active site residues are not freely accessible to interact with the substrates. In the closed state, the two sides are held together firmly with a number of attractive interactions between them (Fig. 4a). As seen from Fig. 4a, the inter-wall interactions include a large number of van der Waals contacts as a series of hydrophobic residues are lined up from both sides. Such a closed state corresponds to the inactive state of the enzyme. In order to open up the substrate binding cleft, the enzyme must be exposed to highly hydrophobic agents such as lipid aggregates or detergents. The substrate binding site has been shown to adopt an open conformation in the presence of detergents [41, 42]. Under the influence of aggregated lipid bilayer or detergents, Wall-2 moves away from Wall-1 so that the cleft adopts an open conformation as a result of which the diffusion of substrates can occur into the cleft leading to the required interactions with the active site residues. The opening of the cleft involves a large scale movement of Wall-2 which is often called as the lid. In the open state, the intraWall contacts are completely lost (Fig. 4b).

The closed and open states are two conditions for the inactive and active states of lipase (Fig. 5). 


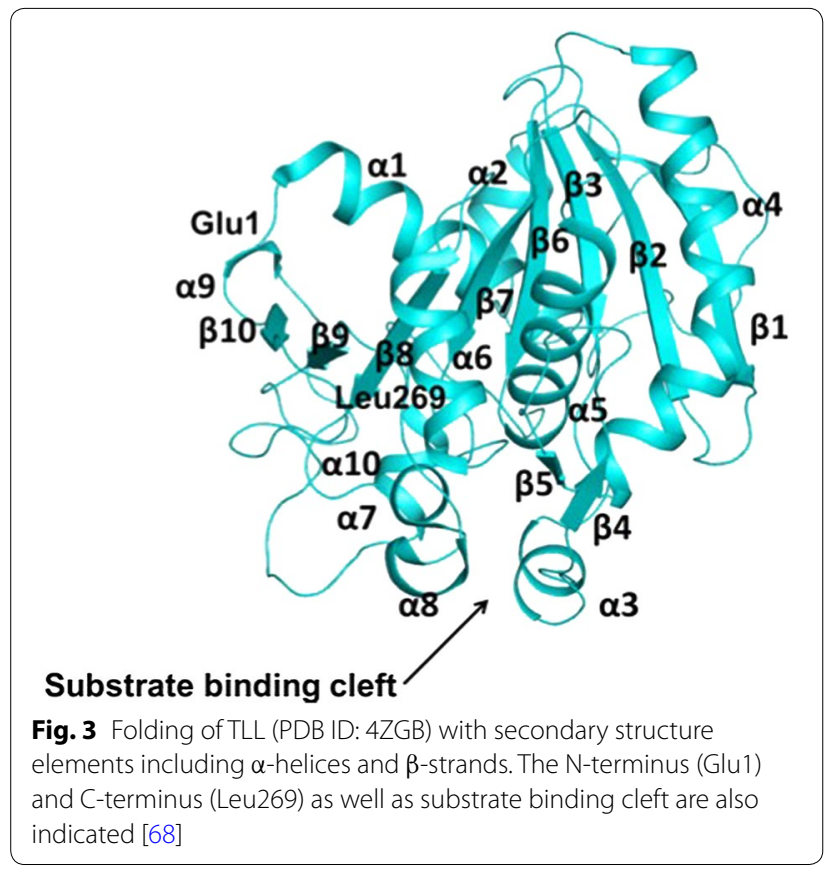

\section{Structure of TLL subjected to TPP}

Crystal structure of TPP-TLL was determined at 2.15 $\AA$ resolution. The overall structure treated form is similar to that of untreated native protein with an r.m.s. shift of $0.7 \AA$ for the $C^{\alpha}$ atoms. The exposure to the interface between the aqueous layer and the upper tert-butanol rich layer was expected to cause a conformational change in the cleft. However, the structure did not indicate the opening of the lid. This is easy to understand since it is well known that interfacial activation of the lipases requires interaction of the lipase in free solution with an interface $[43,44]$. In TPP treatment, the enzyme precipitates out of the solution and cannot interact with the tertbutanol rich layer (unlike the enzyme in free solution). In fact, rather than opening the lid, the TPP treatment resulted in making the active site less accessible due to enhanced molecular rigidity in that region. As a result, the lid further moved closer to the segment on the opposite side thus shortening the lengths of van der Waals contacts (Table 2). The TPP treatment, involving complex interactions of the $\mathrm{SO}_{4}{ }^{2-}$ anions (kosmotropy, conformation tightening and electrostatic forces) simultaneously with interactions with tert-butanol induces a conformational change. Such conformational changes upon TPP treatment have been reported [22, 27, 28, 30, 45]. In the present structure of the TPP-TLL, as seen from Fig. 4c, the two walls moved closer to each other thus optimizing the van der Waals contacts between the two sides of the substrate binding cleft. In this case, the distances of hydrophobic contacts decreased at least by $10 \%$. This suggests that after the TPP treatment, the protein structure becomes more tight and hence more stable than the native state as observed in untreated TLL.

Enhancing the thermal stability of enzymes continues to be a useful goal in biocatalysis [46-48]. Many

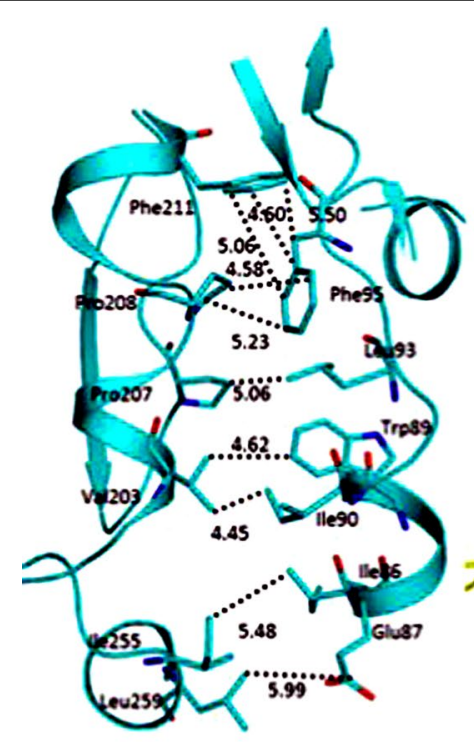

a

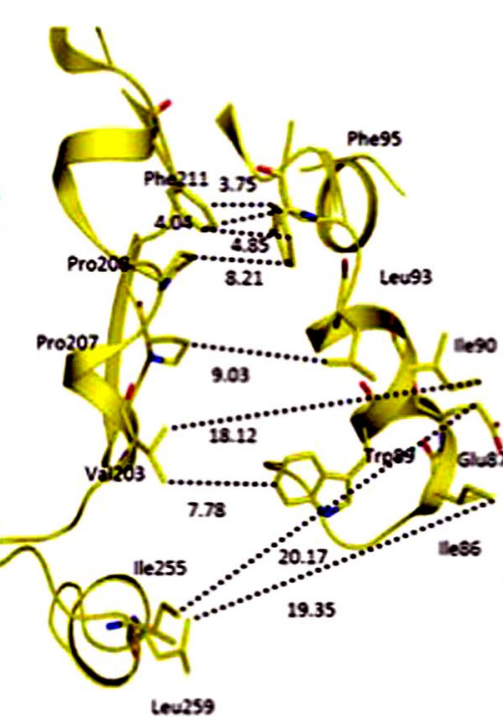

b

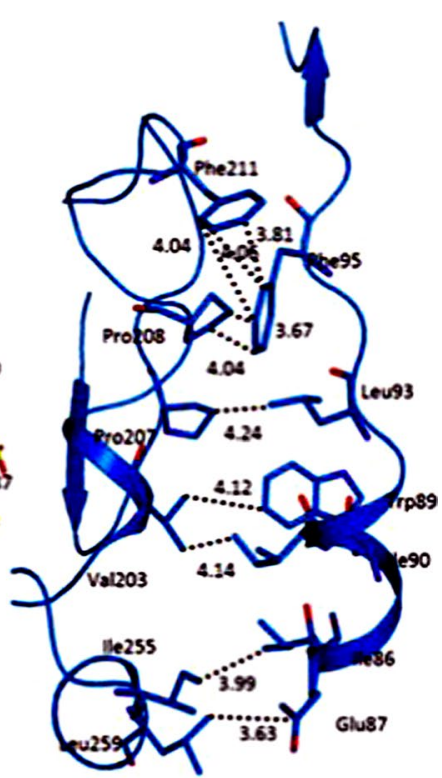

C

Fig. 4 The van der Waals contact distances between atoms of residues from two sides of the cleft in the a native untreated state (PDB ID: 4ZGB), $\mathbf{b}$ presence of a detergent (PDB ID: 1GT6) and c TPP-treated state (PDB ID:4FLF) 


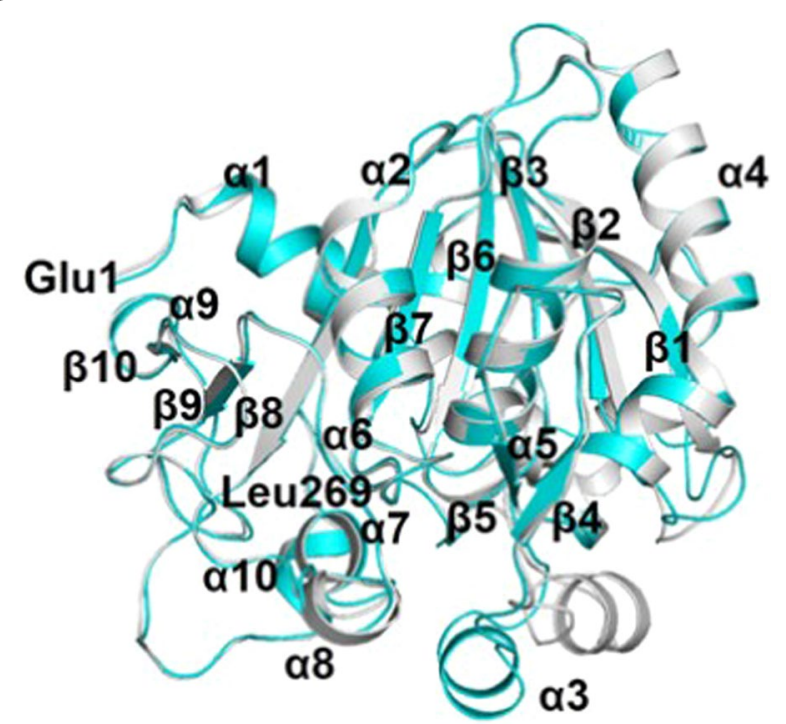

Fig. 5 The superimposition of TPP-treated lipase structure (PDB ID: 4FLF) (cyan) on that of lipase in the presence of detergent (PDB ID: 1GT6) (grey) are shown. The lid (grey) is open in the presence of detergent while it remains closed in the presence of organic solvent

techniques including chemical crosslinking [49-51], immobilization on solid or soluble supports [52-54], protein engineering and directed evolution [55-58] have been employed for this purpose. In the present case, however, it was an incidental result of these studies wherein the aim was to improve both the natural and promiscuous activities of the lipase by subjecting it to TPP as seen with other enzymes [22, 23, 27-30,45]. This is the first example where the TPP treatment seems to have resulted in the increase in the $T_{m}$. In cases reported so far, TPP treatment has resulted in a decrease of thermal stability [30]. The increase in the $T_{m}$ of TLL upon TPP-treatment correlates well with the reduction in the activity. In this regard, it is noteworthy that the substrate binding site became more tight because the distances of the van der Waals contacts between the two sides of the substrate binding channel became considerably shorter than those observed in the untreated protein. This would have made it more difficult for the cleft to open when the substrate approached it. However, in the presence of detergent, the TLL subjected to TPP showed a higher activity because of the more favourable stereochemistry of the active site residues in the treated enzyme. The TLL subjected to TPP was less active and more stable which is good for its shelf life. On the other hand, in the presence of detergent, the TLL subjected to TPP showed activity more than two times higher than the untreated enzyme. An interesting aspect is that the TLL subjected to TPP in the absence of a detergent showed a decrease in the hydrolytic activity which involves hydrolysis of an analogue of a natural substrate, that is, $p$-nitrophenylpalmitate. However, it shows higher activity during catalysis of the promiscuous reaction, that is, aldol condensation. Broos [59] has provided convincing data which shows that changes in flexibility of the enzyme structure may have opposite consequences in terms of selectivity for natural and unnatural substrates. The promiscuous substrates are extreme examples of "unnatural substrates".

It is noteworthy that the TLL subjected to TPP showed 5-fold increase in the initial rates for the aldol condensation (in the presence of $40 \%$ water in acetone as the medium which was also one of the substrates). This reaction was carried out in the absence of detergents, so this involved 'closed lid' structure of the enzyme. Also, one should not overlook the fact that one of the substrates in the promiscuous reaction was acetone. The presence of acetone in the medium was expected to influence the structure of the enzyme. The information about the change or its extent could not unfortunately be obtained by X-ray studies. The efforts to obtain the crystallization of TLL in the presence of acetone did not succeed.

\section{Experimental section}

\section{Materials}

The lipase from Thermomyces lanuginosus was a kind gift from Novozyme A/S (Bagsvaerd, Denmark). $p$-Nitrophenyl palmitate (pNPP) was procured from Sigma-Aldrich Company (St. Louis, USA). All other chemicals used were of analytical grade.

\section{Methods}

\section{Three phase partitioning (TPP) of lipases}

The protocol reported earlier was followed for carrying out the TPP treatment of TLL [60]. The solutions of TLL $(2 \mathrm{~mL}, 20 \mathrm{mg} / \mathrm{mL}$ in $10 \mathrm{mM}$ sodium phosphate buffer, $\mathrm{pH} 7.0$ were saturated with varying concentrations of ammonium sulphate $(w / v)$. This step was followed by the addition of $2 \mathrm{~mL}$ tert-butanol. The solutions were vortexed and allowed to stand at $25^{\circ} \mathrm{C}$ for $1 \mathrm{~h}$. Three phases (i.e., upper layer of tert-butanol, interfacial precipitate of protein and lower aqueous layer) were formed. The solutions were then centrifuged at $2000 \times g$ at $25^{\circ} \mathrm{C}$ for $10 \mathrm{~min}$. The lower aqueous and upper organic layer were separated using a pasteur pipette. The interfacial precipitates obtained were dissolved in $1 \mathrm{~mL}$ of $10 \mathrm{mM}$ sodium phosphate buffer pH 7.0 and dialysed against the same buffer for $24 \mathrm{~h}$ with frequent changes of buffer. This was checked for lipase activity using 4-nitrophenyl palmitate (pNPP) as a substrate [34] and for amounts of protein using Bradford method [61]. The percentage activity and protein in the precipitates were calculated by taking the 
starting amount of activity and protein as $100 \%$. This preparation is referred to as TPP-TLL.

\section{Assay for lipase activity}

The hydrolytic activity of lipase was monitored by measuring the rate of hydrolysis of 4-nitrophenyl palmitate (pNPP) spectrophotometrically at $410 \mathrm{~nm}$ by following the procedure described earlier [34]. The reaction mixtures consisted of $1.8 \mathrm{~mL}$ of buffer $(10 \mathrm{mM}$ sodium phosphate, $\mathrm{pH} 7.0$ containing $150 \mathrm{mM} \mathrm{NaCl}$ [and with or without $0.5 \%(\mathrm{v} / \mathrm{v})$ triton X-100]), $0.2 \mathrm{~mL}$ of enzyme solution in $10 \mathrm{mM}$ sodium phosphate buffer, $\mathrm{pH} 7.0$ and $20 \mu \mathrm{l}$ of $50 \mathrm{mM}$ substrate pNPP in acetonitrile. The mixtures were incubated for $30 \mathrm{~min}$ at $37^{\circ} \mathrm{C}$ and after this the samples were kept in a domestic microwave oven along with a beaker containing a volume of water sufficient to make the total volume of the liquid in the cavity as $100 \mathrm{~mL}$ (the additional water absorbs a significant amount of microwave energy, this was done to avoid overheating of the sample) and irradiated for $30 \mathrm{~s}$ and read at $410 \mathrm{~nm}$. One unit (U) of enzyme activity is defined as the amount of the enzyme that liberates $1 \mu \mathrm{mol}$ of 4-nitrophenol per min at $\mathrm{pH} 7.0$ and $37^{\circ} \mathrm{C}$.

\section{Protein estimation}

Protein concentrations were determined according to the procedure described by Bradford [61]. Protein solutions $(0.5 \mathrm{~mL})$ were incubated with $4.5 \mathrm{~mL}$ of the dye reagent at $25{ }^{\circ} \mathrm{C}$ for $10 \mathrm{~min}$ and the absorbance of the solutions were read at $595 \mathrm{~nm}$ and bovine serum albumin was used as the standard protein.

\section{Measurement of the melting temperature $\left(T_{m}\right)$}

The melting temperature of TLL and TPP-TLL were determined by using circular dichroism studies. Thermal denaturation curves were determined directly by monitoring the ellipticity changes at $222 \mathrm{~nm}$. The samples with a concentration of $0.2 \mathrm{mg} \mathrm{mL}^{-1}$ were used. The temperature of sample solution was raised linearly by $1{ }^{\circ} \mathrm{C} \mathrm{min}{ }^{-1}$ from 50 to $100{ }^{\circ} \mathrm{C}$. The heating curves were corrected for an instrumental baseline obtained by heating the buffer (10 mM sodium phosphate, $\mathrm{pH}$ 7.0) alone. The melting temperature $\left(\mathrm{T}_{\mathrm{m}}\right)$ was calculated from the first-order derivatives of the ellipticity-temperature plot.

\section{Crystallization}

The samples of both (1) non-treated lipase (TLL) and (2) the lipase subjected to three phase partitioning (TPPTLL) were dissolved in solution containing $0.1 \mathrm{M}$ HEPES buffer, $1 \mathrm{M} \mathrm{NaCl} \mathrm{pH} 7.5$ at a concentration of $30 \mathrm{mg} / \mathrm{mL}$ to make solutions (1) and (2), respectively. The drops of $10 \mu \mathrm{l}$ of solutions (1) and (2) were prepared for the hanging drop vapour diffusion method. The protein drops were equilibrated against $1.6 \mathrm{M}$ ammonium sulphate. The rectangular shaped crystals measuring up to dimensions of $0.4 \times 0.3 \times 0.3 \mathrm{~mm}^{3}$ were obtained after 3 weeks from the drops of the solutions. The crystals from the two samples were washed with reservoir buffer before placing them into a fresh solution containing reservoir buffer and $25 \%$ glycerol as a cryoprotectant for data collection at low temperatures.

\section{Data collection and processing}

Two X-ray intensity data sets were collected on the crystals of (1) TLL and (2) TPP-TLL with MAR CCD-225 Scanner (Mar research, Norderstedt, Germany) using the beamline, BM14 at the European Synchrotron Radiation Facility (ESRF), Grenoble, France. The reflections of both the data sets were indexed and scaled using the program, HKL2000 [62]. The summary of data collection statistics is given in Table 3.

\section{Structure determinations and refinements}

The structure of TLL was determined with molecular replacement method [63] using the coordinates of lipase in its unbound state (PDB code: 1DT3) [18]. This produced a clear solution with two peaks. Initially, the structure was refined for 20 cycles using REFMAC 5.5 [64]. The coordinates of partially refined structure of TLL were used as the starting model for refining the TPP-TLL structure. The initial calculations for 25 cycles were carried out as the rigid body refinement. The electron density maps with $\left(2 \mathrm{~F}_{\mathrm{o}}-\mathrm{F}_{\mathrm{c}}\right)$ and $\left(\mathrm{F}_{\mathrm{o}}-\mathrm{F}_{\mathrm{c}}\right)$ coefficients were calculated. The models were improved by manual model building with programs $O$ [65] and Coot [66] using graphics workstations. After another 25 cycles of refinements, when the values of $R_{\text {cryst }} / R_{\text {free }}$ factors dropped to less than $0.27 / 0.30$, Fourier maps with $\left(2 \mathrm{~F}_{\mathrm{o}}-\mathrm{F}_{\mathrm{c}}\right)$ and $\left(\mathrm{F}_{\mathrm{o}}-\right.$ $F_{c}$ ) coefficients were calculated for both the structures. These maps were used for determining the positions of water oxygen atoms in both structures. The coordinates of 245 water oxygen atoms were obtained in the TLL structure while the coordinates of 288 water oxygen were determined in the TPP-TLL structure. These coordinates were included in the final cycles of refinements. The refinements finally converged to values of $0.221 / 0.270$ and $0.227 / 0.268$ for the $R_{\text {cryst }} / R_{\text {free }}$ factors of the untreated and treated structures. The final refinement statistics are included in Table 3. The refined atomic coordinates of structures of TLL and TPP-TLL have been deposited in the protein data bank with accession codes of $4 \mathrm{ZGB}$ and 4FLF respectively.

\section{Conclusions}

The present studies did reveal some interesting information: 
Table 3 Crystallographic data collection and refinement statistics

\begin{tabular}{|c|c|c|}
\hline Parameters & TLL & TPP-TLL \\
\hline Resolution range $(\AA)$ & $50.00-2.30$ & $50.00-2.15$ \\
\hline Space group & $\mathrm{P}_{1}$ & $P 6_{1}$ \\
\hline \multicolumn{3}{|l|}{ Unit cell parameters } \\
\hline$a=b(\AA)$ & 140.1 & 139.9 \\
\hline$c(\AA)$ & 80.5 & 80.0 \\
\hline Number of molecules in the asymmetric unit & 2 & 2 \\
\hline Total number of measured reflections & 169,548 & 671,375 \\
\hline Number of unique reflections & 37,653 & 46,024 \\
\hline Completeness (\%) & $98.8(90.0)$ & $99.2(95.4)$ \\
\hline $\mathrm{I} / \sigma(\mathrm{I})$ & $26.8(4.0)$ & $33.0(2.1)$ \\
\hline Rsym (\%) & $6.9(23.8)$ & $8.6(41.3)$ \\
\hline \multicolumn{3}{|l|}{ Refinement } \\
\hline $\mathrm{R}_{\text {cryst }}(\%)$ & 18.2 & 22.7 \\
\hline $\mathrm{R}_{\text {free }}(\%)$ & 20.6 & 26.8 \\
\hline R.m.s.d in bond lengths ( $\AA$ ) & 0.02 & 0.02 \\
\hline R.m.s.d in bond angles $\left(^{\circ}\right)$ & 2.2 & 2.1 \\
\hline R.m.s.d in torsion angles $\left(^{\circ}\right)$ & 17.4 & 18.1 \\
\hline \multicolumn{3}{|l|}{ Ramachandran plot analysis } \\
\hline Most favoured (\%) & 88.2 & 88.3 \\
\hline Additionally allowed (\%) & 10.1 & 9.5 \\
\hline Generously allowed region (\%) & 1.3 & 1.3 \\
\hline Disallowed region (\%) & 0.4 & 0.9 \\
\hline \multicolumn{3}{|l|}{ B factors $\left(\AA^{2}\right)$} \\
\hline Wilson B factor & 37.6 & 37.8 \\
\hline Average B-factor for main chain atoms & 41.6 & 36.7 \\
\hline Average B-factor for the side chain atoms and water oxygen atoms & 42.1 & 38.7 \\
\hline Mean B-factor for all atoms & 41.8 & 37.8 \\
\hline Number of protein atoms & 4142 & 4142 \\
\hline Number of water oxygen atoms & 245 & 288 \\
\hline Number of carbohydrate (NAG) residues & 0 & 2 \\
\hline PDB ID & $4 Z G B$ & $4 F L F$ \\
\hline
\end{tabular}

The values in parentheses correspond to the values in the highest resolution shell

1. In the case of TLL, TPP treatment introduces a rigidity rather than flexibility around the active site region.

2. Upon opening up the lid by interfacial activation, TLL subjected to TPP assumes a structure which was more along the expected lines. As in the case of proteinase $K$ [28], it might be more flexible in the state with an open lid than the native structure. This might have led to the significant increase in the enzyme activity.

Three phase partitioning has slowly emerged as a simple approach to subtly alter conformational flexibility. Even subtle changes in conformational flexibility are important for both natural and promiscuous reactions of enzymes and influence even their enantioselectivity [67].
The present work shows that TLL subjected to TPP behaves differently while it exists as a "closed lid" structure and as an "open lid" structure. In the "closed lid structure", TLL subjected to TPP has enhanced rigidity while the opening of the lid by well known interfacial activation removes this rigidity. The results are also useful in the context of understanding the role which conformational flexibility plays in catalytic promiscuity.

\section{Authors' contributions}

The group at AIIMS (MK, MS, PK, SS and TPS) were involved in the crystallization of the enzyme and its complexes, interpretation of the X-ray data and discussion with the IITD group. JM carried out the experimental work consisting the activity assay, $T_{m}$ measurements etc. MNG suggested probing TLL activity with or without TPP treatment and correlating the results of the X-ray studies with the biochemical implications. All authors read and approved the final manuscript. 


\section{Author details}

${ }^{1}$ Department of Biophysics, All India Institute of Medical Sciences, New Delhi, India. ${ }^{2}$ Chemistry Department, Indian Institute of Technology Delhi, New Delhi, India. ${ }^{3}$ Department of Biochemical Engineering and Biotechnology, Indian Institute of Technology Delhi, New Delhi, India.

\section{Acknowledgements}

This work was supported by Grants from the Department of Science and Technology (DST-SERB), Govt. of India (Grant No. SR/SO/BB-68/2010) to the IITD. The AlIMS group also thanks Department of Science and Technology (DST), New Delhi and Department of Biotechnology (DBT), New Delhi for financial support. TPS also thanks the Indian National Science Academy for the grant of position of INSA-Senior Scientist. JM thanks CSIR (Govt. of India) for the senior research fellowship.

\section{Compliance with ethical guidelines}

\section{Competing interests}

The authors declare that they have no competing interests.

Received: 3 July 2015 Accepted: 15 September 2015

Published online: 24 September 2015

\section{References}

1. Fessner WD, Anthonsen T (2008) Modern biocatalysis: stereoselective and environmentally friendly reactions. Wiley, New York

2. Gupta MN (1992) Enzyme function in organic solvents. Eur J Biochem 203:25-32

3. Carrea G, Riva S (2000) Properties and synthetic applications of enzymes in organic solvents. Angew Chem Int Ed Engl 39:2226-2254

4. Gupta MN (ed) (2000) Methods in non-aqueous enzymology. BirkhäuserVerlag, Basel

5. Halling PJ (2000) Biocatalysis in low-water media: understanding effects of reaction conditions. Curr Opin Chem Biol 4:74-80

6. Hudson EP, Eppler RK, Clark DS (2005) Biocatalysis in semi-aqueous and nearly anhydrous conditions. Curr Opin Biotechnol 16:637-643

7. Mattiasson B, Adlercreutz P (1991) Tailoring the microenvironment of enzymes in water-poor systems. Trends Biotechnol 9:394-398

8. Adlercreutz P (2013) Immobilisation and application of lipases in organic media. Chem Soc Rev 42:6406-6436

9. Kapoor M, Gupta MN (2012) Lipase promiscuity and its biochemical applications. Process Biochem 47:555-569

10. Khersonsky O, Tawfik DS (2010) Enzyme promiscuity: a mechanistic and evolutionary perspective. Annu Rev Biochem 79:471-505

11. Busto E, Gotor-Fernández V, Gotor V (2010) Hydrolases: catalytically promiscuous enzymes for non-conventional reactions in organic synthesis. Chem Soc Rev 39:4504-4523

12. Arora B, Pandey PS, Gupta MN (2014) Lipase catalyzed Cannizzaro-type reaction with substituted benzaldehydes in water. Tetrahedron Lett 55:3920-3922

13. Malhotra D, Mukherjee J, Gupta MN (2015) Sustainability of biocatalytic processes. In: Letcher T, Scott JL, Patterson DA (eds) Chemical processes for a sustainable future. Royal Society of Chemistry, Cambridge

14. Hult K, Berglund P (2007) Enzyme promiscuity: mechanism and applications. Trends Biotechnol 25:231-238

15. Arora B, Mukherjee J, Gupta MN (2014) Enzyme promiscuity: using the dark side of enzyme specificity in white biotechnology. Sustain Chem Process 2:25

16. Li N, Zong M-H, Ma D (2009) Unexpected reversal of the regioselectivity in Thermomyces lanuginosus lipase-catalyzed acylation of floxuridine. Biotechnol Lett 31:1241-1244

17. Derewenda U, Swenson L, Wei Y, Green R, Kobos PM, Joerger R, Haas MJ, Derewenda ZS (1994) Conformational lability of lipases observed in the absence of an oil-water interface: crystallographic studies of enzymes from the fungi Humicola lanuginosa and Rhizopus delemar. J Lipid Res 35:524-534

18. Brzozowski AM, Savage H, Verma CS, Turkenburg JP, Lawson DM, Svendsen A, Patkar S (2000) Structural origins of the interfacial activation in Thermomyces (Humicola) lanuginosa lipase. Biochemistry 39:15071-15082
19. Fernandez-Lafuente R (2010) Lipase from Thermomyces lanuginosus: uses and prospects as an industrial biocatalyst. J Mol Catal B 62:197-212

20. Cai JF, Guan Z, He YH (2011) The lipase-catalyzed asymmetric C-C Michael addition. J Mol Catal B Enzym 68:240-244

21. Lovrein RE, Goldensoph C, Anderson P, Odegard B (1987) Three phase partitioning (TPP) via t-butanol: enzyme separation from crudes. In: Burgess $R$ (ed) Protein purification, micro to macro. Marcel Dekker Inc., New York

22. Dennison C, Lovrien R (1997) Three phase partitioning: concentration and purification of proteins. Protein Expr Purif 11:149-161

23. Roy I, Gupta MN (2004) $\alpha$-Chymotrypsin shows higher activity in water as well as organic solvents after three phase partitioning. Biocatal Biotransform 22:261-268

24. Narayan AV, Madhusudhan MC, Raghavarao KS (2008) Extraction and purification of Ipomoea peroxidase employing three-phase partitioning. Appl Biochem Biotechnol 151:263-272

25. Roy I, Sharma A, Gupta MN (2004) Obtaining higher transesterification rates with subtilisin Carlsberg in nonaqueous media. Bioorg Med Chem Lett 14:887-889

26. Raghava S, Barua B, Singh PK, Das M, Madan L, Bhattacharyya S, Bajaj K, Gopal B, Varadarajan R, Gupta MN (2008) Refolding and simultaneous purification by three-phase partitioning of recombinant proteins from inclusion bodies. Protein Sci 17:1987-1997

27. Lovrein RE, Conroy MJ, Richardson TI, Gregory RB (1995) Protein solvent interactions. Marcel Dekker Inc., New York

28. Singh RK, Gourinath S, Sharma S, Roy I, Gupta MN, Betzel C, Srinivasan A, Singh TP (2001) Enhancement of enzyme activity through three-phase partitioning: crystal structure of a modified serine proteinase at $1.5 \mathrm{~A}$ resolution. Protein Eng 14:307-313

29. Rather GM, Mukherjee J, Halling PJ, Gupta MN (2012) Activation of alpha chymotrypsin by three phase partitioning is accompanied by aggregation. PLoS One 7:e49241

30. Rather GM, Gupta MN (2013) Three phase partitioning leads to subtle structural changes in proteins. Int J Biol Macromol 60:134-140

31. Rather GM, Gupta MN (2013) Refolding of urea denatured ovalbumin with three phase partitioning generates many conformational variants. Int J Biol Macromol 60:301-308

32. Singh N, Jabeen T, Sharma S, Roy I, Gupta MN, Bilgrami S, Somvanshi RK, Dey S, Perbandt M, Betzel C, Srinivasan A, Singh TP (2005) Detection of native peptides as potent inhibitors of enzymes. Crystal structure of the complex formed between treated bovine alpha-chymotrypsin and an autocatalytically produced fragment, Ile-Val-Asn-Gly-Glu-Glu-Ala-Val-ProGly-Ser-Trp-Pro-Trp, at 2.2 angstroms resolution. FEBS J 272:562-572

33. Mukherjee J, Mishra P, Gupta MN (2015) Urea treated subtilisin as a biocatalyst for transformations in organic solvents. Tetrahedron Lett 56:1976-1981

34. Jain P, Jain S, Gupta MN (2005) A microwave-assisted microassay for lipases. Anal Bioanal Chem 381:1480-1482

35. Mogensen JE, Sehgal P, Otzen DE (2005) Activation, inhibition, and destabilization of Thermomyces lanuginosus lipase by detergents. Biochemistry 44:1719-1730

36. Shah S, Gupta MN (2007) Obtaining high transesterification activity for subtilisin in ionic liquids. Biochim Biophys Acta 1770:94-98

37. Bastida A, Sabuquillo P, Armisen P, Fernández-Lafuente R, Huguet J, Guisán JM (1998) A single step purification, immobilization, and hyperactivation of lipases via interfacial adsorption on strongly hydrophobic supports. Biotechnol Bioeng 58:486-493

38. Fernandez-Lafuente R, Armisén P, Sabuquillo P, Fernández-Lorente G, Guisán JM (1998) Immobilization of lipases by selective adsorption on hydrophobic supports. Chem Phys Lipids 93:185-197

39. Yilmaz E (2002) Improving the application of microbial lipase by bio-imprinting at substrate-interfaces. World J Microbiol Biotechnol 18:37-40

40. Fishman A, Cogan U (2003) Bio-imprinting of lipases with fatty acids. J Mol Catal B 22:193-202

41. Yapoudjian S, Ivanova MG, Brzozowski AM, Patkar SA, Vind J, Svendsen A, Verger R (2002) Binding of Thermomyces (Humicola) lanuginosa lipase to the mixed micelles of cis-parinaric acid/NaTDC. Eur J Biochem 269:1613-1621

42. de Diego T, Lozano P, Gmouh S, Vaultier M, Iborra JL (2005) Understanding structure-stability relationships of Candida antartica lipase B in ionic liquids. Biomacromolecules 6:1457-1464

43. Desnuelle P (1961) Pancreatic lipase. Adv Enzymol 23:129-161 
44. Brockman HL, Law JH, Kézdy FJ (1973) Catalysis by adsorbed enzymes. The hydrolysis of tripropionin by pancreatic lipase adsorbed to siliconized glass beads. J Biol Chem 248:4965-4970

45. Sharma A, Roy I, Gupta MN (2004) Affinity precipitation and macroaffinity ligand facilitated three-phase partitioning for refolding and simultaneous purification of urea-denatured pectinase. Biotechnol Prog 20:1255-1258

46. Santoro MM, Liu Y, Khan SM, Hou LX, Bolen DW (1992) Increased thermal stability of proteins in the presence of naturally occurring osmolytes. Biochemistry 31:5278-5283

47. Gupta MN (ed) (1993) Thermostability of enzymes. Springer, Heidelberg

48. Kuznetsova IM, Turoverov KK, Uversky VN (2014) What macromolecular crowding can do to a protein. Int J Mol Sci 15:23090-23140

49. Khare SK, Gupta MN (1988) A preparation of E. coli beta galactosidase. Appl Biochem Biotechnol 16:1-15

50. Tyagi R, Gupta MN (1998) Chemical modification and chemical crosslinking of protein/enzyme stabilization. Biochem (Moscow) 63:334-344

51. Yamazaki T, Tsugawa W, Sode K (1999) Increased thermal stability of glucose dehydrogenase by crosslinking chemical modification. Biotechnol Lett 21:199-202

52. Cao L (2005) Carrier bound immobilized enzymes: principles, application and design. Wiley-VCH Verlag GmbH and Co., Weinheim

53. Minteer SD (ed) (2011) Enzyme stabilization and immobilization: methods and protocols. Humana Press, New York

54. Guisan JM (ed) (2013) Immobilization of enzymes and cells. Humana Press, New York

55. Carey PR (ed) (1996) Protein engineering and design. Academic, New York

56. Nosoh Y, Sekiguchi T (1993) Protein engineering for thermostabilization. In: Gupta MN (ed) Thermostabilization of enzymes. Springer, Heidelberg pp 182-204

57. Arnold FH, Georgiou G (2003) Directed enzyme evolution: screening and selection methods. Humana Press, Totowa
58. Arnold FH, Georgiou G (2003) Directed evolution library construction: methods and protocol. Humana Press, Totowa

59. Broos J (2002) Impact of the enzyme flexibility on the enzyme enantioselectivity in organic media towards specific and non-specific substrates. Biocatal Biotransform 20:291-295

60. Mondal K, Roy I, Gupta MN (2006) Affinity-based strategies for protein purification. Anal Chem 78:3499-3504

61. Bradford MM (1976) A rapid and sensitive method for the quantitation of microgram quantities of protein utilizing the principle of protein-dye binding. Anal Biochem 72:248-254

62. Otwinowski Z, Minor W (1997) Denzo and scalepack. Meth Enzymol 276:307-326

63. Vagin A, Teplyakov A (2010) Molecular replacement with MOLREP. Acta Crystallogr D Biol Crystallogr 66:22-25

64. Murshudov GN, Skubák P, Lebedev AA, Pannu NS, Steiner RA, Nicholls RA, Winn MD, Long F, Vagin AA (2011) REFMAC5 for the refinement of macromolecular crystal structures. Acta Crystallogr D Biol Crystallogr 67:355-367

65. Jones TA, Zou JY, Cowan SW, Kjeldgaard M (1991) Improved methods for building protein models in electron density maps and the location of errors in these models. Acta Crystallogr A 47:110-119

66. Emsley P, Cowtan K (2004) Coot: model-building tools for molecular graphics. Acta Crystallogr D Biol Crystallogr 60:2126-2132

67. Mukherjee J, Gupta MN (2015) Increasing importance of protein flexibility in designing biocatalytic processes. Biotechnol Rep 6:119-123

68. DeLano WL (2005) The case for open-source software in drug discovery. Drug Discov Today 10:213-217

\section{Publish with ChemistryCentral and every scientist can read your work free of charge \\ "Open access provides opportunities to our colleagues in other parts of the globe, by allowing anyone to view the content free of charge."}

W. Jeffery Hurst, The Hershey Company.

- available free of charge to the entire scientific community

- peer reviewed and published immediately upon acceptance

- cited in PubMed and archived on PubMed Central

- yours - you keep the copyright

Submit your manuscript here:

http://www.chemistrycentral.com/manuscript/ 